\title{
CASTOR BEAN CAKE IN TOP-DRESSING APPLICATION AS A SOURCE OF NITROGEN ON THE PRODUCTION AND QUALITY OF ZUCCHINI ORGANIC SEEDS
}

\author{
TORTA DE MAMONA EM COBERTURA COMO FONTE DE NITROGENNIO NA \\ PRODUÇÃO E QUALIDADE DE SEMENTES ORGÂNICAS DE ABOBRINHA-DE- \\ MOITA
}

\section{Natália de Brito Lima LANNA ${ }^{1 *}$; Estefânia Martins BARDIVIESSO ${ }^{1}$; Ana Emília Barbosa TAVARES ${ }^{2}$; Priscilla Nátaly de Lima SILVA ${ }^{1}$; Pâmela Gomes NAKADA-FREITAS ${ }^{3}$; Sayuri Beatriz Hara NODA ${ }^{1}$; Antonio Ismael Inácio CARDOSO ${ }^{1}$}

1. Department of Horticulture, Paulista State University “Júlio de Mesquita Filho" - College of Agricultural Science, Botucatu, SP, Brazil; 2. Integrated Faculties Aparício Carvalho, Porto Velho, RD, Brazil; 3. Department of Crop Science, Paulista State University "Júlio de Mesquita Filho" - College of Agricultural and Technological Sciences, Dracena, SP, Brazil.

* nataliabllanna@gmail.com

\begin{abstract}
Studies in vegetables show that fertilization influences seed production positively, however, when the quality of the seeds is analyzed, the results are mostly inconsistent. The objective of this study was to evaluate the effect of castor bean cake (CBC) dose splitting in top-dressing application on the production and quality of zucchini organic seeds, as well as its effect on the macronutrient content of fruits and seeds. The experimental design was a randomized block design and four replications. There were 13 treatments with four doses of CBC in top-dressing $\left(1.7,3.4,5.1\right.$ and $\left.6.8 \mathrm{t} \mathrm{ha}^{-1}\right)$ per three applications $(33.3-33.3-33.3 \%$, $50-50 \%$ and $33-50-17 \%$ ) and the control treatment without any kind of top-dressing fertilization. The study evaluated the number of ripe fruits per plant, the production (number and mass) of seeds per fruit and per plant, the mass of one hundred seeds, seed germination, first germination count, and macronutrient content in the diagnosis leaf, in mature fruits (without seeds) and seeds. The number of ripe fruits per plant was not affected by the $\mathrm{CBC}$ doses in top-dressing, neither by the splitting of the applications. It was observed that the number of seeds per fruit, mass of seeds per fruit and mass of seeds per plant showed quadratic behavior. Regarding seed quality, only the $1.7 ; 3.4$ and $5.1 \mathrm{t} \mathrm{ha}^{-1}$ doses produced seed with superior quality than the other doses. In conclusion, the $\mathrm{CBC}$ doses increased the number of seeds per fruit, mass of seeds per fruit and per plant up to the $4.5 \mathrm{t} \mathrm{ha}^{-1}$ dose, approximately.
\end{abstract}

KEYWORDS: Cucurbita pepo. Germination. Nitrogen fertilization. Organic fertilization. Vigor.

\section{INTRODUCTION}

Organic production is increasing more and more, but there is still a lack of management information on the production of organic seeds. According to the Normative Instruction 64/2008 of the Ministry of Agriculture, Livestock and Food Supply (MAPA) of December 2008, if there is no availability of organic seeds and seedlings, the use of other materials on the market may be authorized. Preference must be given to those which have not received any treatment with pesticides or other substances not allowed by the Normative Instruction.

The few studies available indicate that fertilization influences seed production positively. However, when the quality of the seeds is analyzed, the results are mostly inconsistent. According to
Carvalho and Nakagawa (2012), a well-nourished plant is able to produce more well-formed seeds. However, there are reports that even with insufficient fertilization seed quality is not significantly affected, although production can be reduced (MAGRO et al., 2010; KANO et al., 2012). It is also reported that the effect of plant nutrition on seed quality can be observed only after the seeds have been stored for some time (KANO et al. 2011; MAGRO; CARDOSO; FERNANDES, 2012).

The adequate knowledge of the doses and correct fertilization practices is fundamental to obtain higher productivity of fruits and seeds. This would avoid the lack or excess of nutrients available to the plant, promoting sustainable agricultural practices. It is very common to use fertilization recommendations for the production of vegetables for consumption for seed production. The zucchini, 
as other vegetables, is largely consumed in its immature state, when its seeds are still being formed. The peak of nutrient uptake takes place when the seeds are maturing, which become the main drain of the plant. However, in the horticultural area, there is a lack of information regarding the effects of organic fertilization on the production and quality of seeds.

Plant materials, mainly castor bean cake, are rich in nitrogen and have been used by organic producers as a source of this nutrient in coverage application (SILVA; LANNA; CARDOSO, 2016). However, no studies were found on its use in the production of fruits and seeds of zucchini or other cucurbits.

Plants require different nutrient quantities throughout their growth, so the availability of nutrients (mainly nitrogen), especially when they are most demanded, is essential guarantee good production and quality of seeds.

The objective of this study was to evaluate the effect of splitting and doses of castor bean cake in top-dressing application in the production and quality of zucchini seeds, as well as, the level of macronutrients of fruits and seeds.

\section{MATERIAL AND METHODS}

The experiment was conducted at the Fazenda Experimental São Manuel, located in the municipality of São Manuel in the state of São Paulo, belonging to the Faculdade de Ciências Agronômicas (FCA) of the Universidade Estadual Paulista (UNESP), Campus of Botucatu-SP, Brazil (Figure 1).

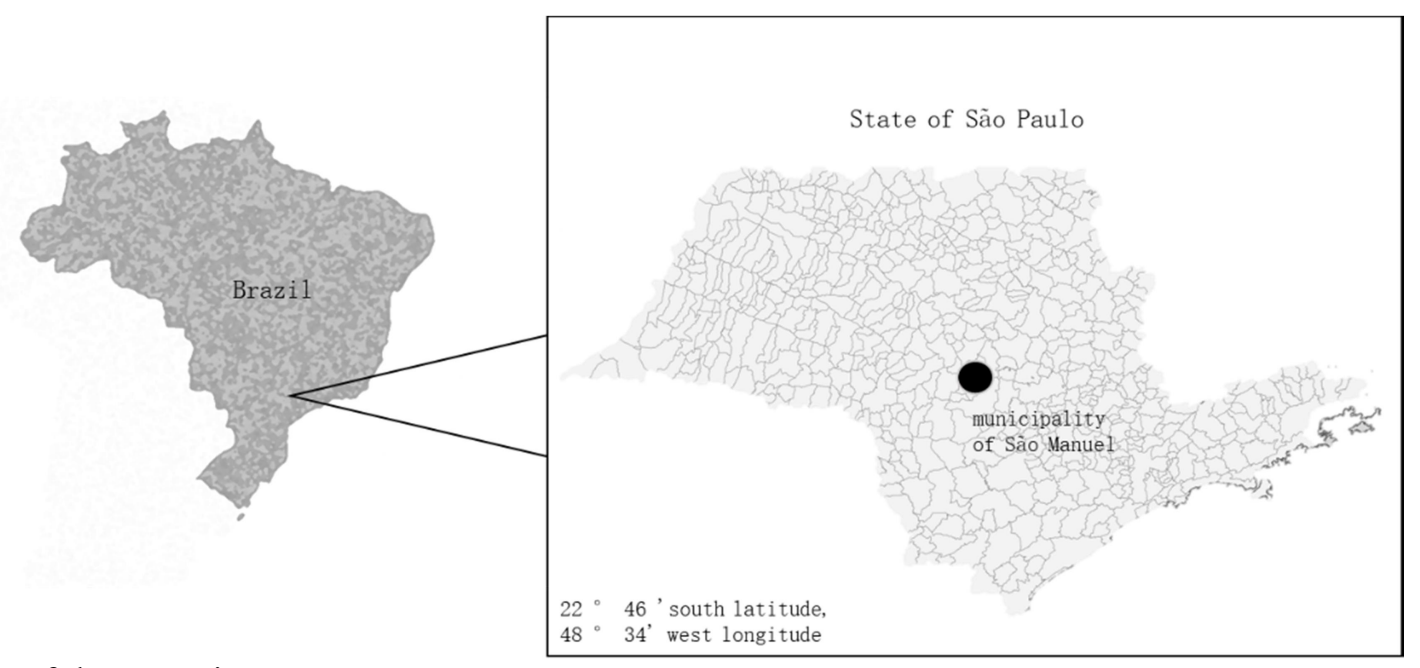

Figure 1. Location of the Experiment.

The region's climate has a $C f a$ Köppen classification, temperate mesothermal and humid (CUNHA; MARTINS, 2009). The geographical coordinates of the area are: $22^{\circ} 46^{\prime}$ south latitude, $48^{\circ} 34^{\prime}$ west longitude and an altitude of $740 \mathrm{~m}$. Figure 2 shows the maximum, minimum and mean temperatures and precipitation index.

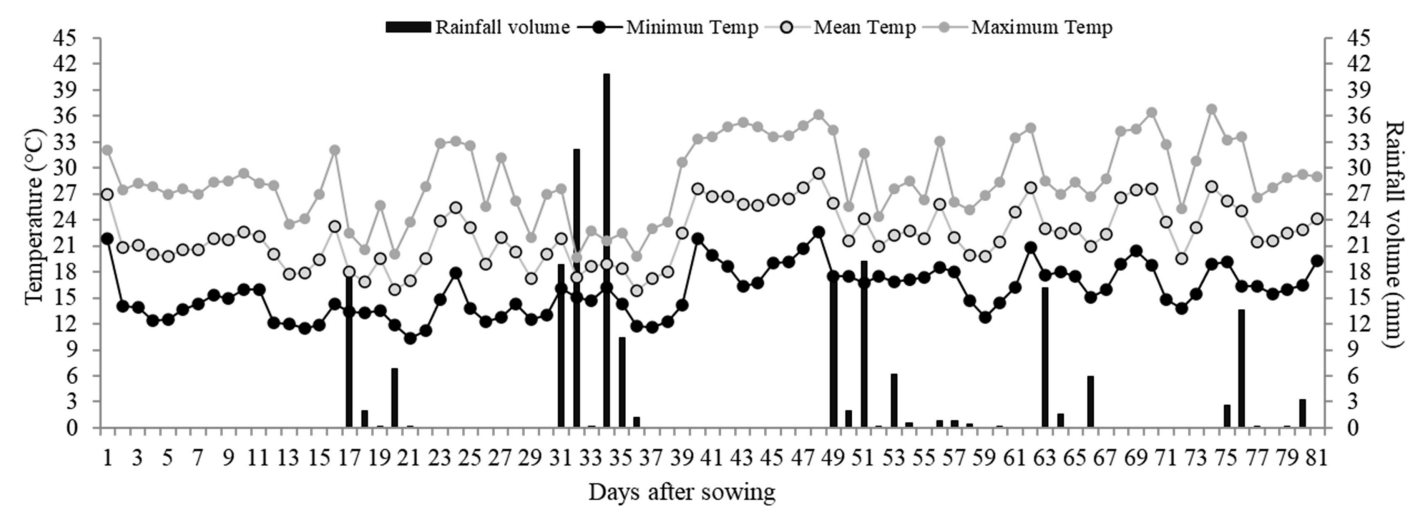

Figure 2. Maximum, minimum and mean temperatures; precipitation index referring to the city of São Manuel, SP, during the experiment. 
The soil of the area is a Typical Dystrophic Red Latosol. The following soil analysis values were obtained: $\mathrm{pH}\left(\mathrm{CaCl}_{2}\right)=5.7 ; \mathrm{MO}=21 \mathrm{~g} \mathrm{dm}^{-3}$; $\mathrm{P}_{\text {resina }}=184$

$\mathrm{mg} \mathrm{dm}{ }^{-3} ; \mathrm{H}+\mathrm{Al}=19 \mathrm{mmolc} \mathrm{dm}^{-3} ; \mathrm{K}=5.4$ mmolc dm ${ }^{-3} ; \mathrm{Ca}=37$ mmolc $\mathrm{dm}^{-3} ; \mathrm{Mg}=14$ mmolc $\mathrm{dm}^{-3} ; \mathrm{SB}=57 \mathrm{mmolc} \mathrm{dm}^{-3} ; \mathrm{CTC}=76$ mmolc $\mathrm{dm}^{-3}$; $\mathrm{V}=75 \%$.

\section{Treatments and experimental design}

13 treatments were studied, resulting from the factorial scheme $(4 \times 3+1)$. The treatments were: four castor bean cake doses in top-dressing $(1.7 ; 3.4$; 5.1 ; and $\left.6.8 \mathrm{t} \mathrm{ha}^{-1}\right) \times$ three splittings of those applications (33.3-33.3-33.3\%; 50-50\% and 33-50$17 \%$ ) and the control treatment without any kind of fertilization in top-dressing (zero dose), only the organic fertilization before planting. In the first splitting application, the doses were divided in three applications $33.3-33.3-33.3 \%$ of the total dose at 15 , 30 and 45 days after transplant (DAT). In the second splitting application, $50-50 \%$ of the total dose was applied at 15 and $30 \mathrm{DAT}$, and in the last splitting application, 33-50-17\% of the total dose was applied at 15, 30 and 45 DAT. The experimental design was randomized block design, with four replicates.

The doses of castor bean cake were calculated from the its chemical analysis $(\mathrm{N}=5.7$; $\mathrm{P}_{2} \mathrm{O}_{5}=1.0 ; \mathrm{K}_{2} \mathrm{O}=0.9 ; \mathrm{Ca}=1.7 ; \mathrm{Mg}=0.4 ; \mathrm{S}=0.3$; $\mathrm{U}-65^{\circ} \mathrm{C}=9.03 ;$ MO-total $=82.0 ;$ C-total $=46.0$, all were calculated in dry mass percentage), considering the humidity $(9.03 \%)$ and the $\mathrm{N}$ topdressing recommendation by Trani and Van Raij $(1997)$ for this species $\left(150 \mathrm{~kg} \mathrm{ha}^{-1}\right.$ of $\left.\mathrm{N}\right)$. Thus, 0 ; $75 ; 150 ; 225$ and $300 \mathrm{~kg} \mathrm{ha}^{-1}$ of $\mathrm{N}$ were applied with the doses of castor bean cake, which is $0-200 \%$ of the dose recommended by these authors. The authors also recommend the application of $\mathrm{K}$ in topdressing, so potassium sulfate $\left(\mathrm{K}_{2} \mathrm{SO}_{4}\right)$ was applied $\left(90 \mathrm{~kg} \mathrm{ha}^{-1}\right)$, split in three applications at 15,30 and 45 DAT, for all treatments.

For planting fertilization in organic fertilizer treatments, the average of the recommendations of Trani and Van Raij (1997) was used, $30 \mathrm{t} \mathrm{ha}^{-1}$ of organic compound. The following values were obtained in the chemical analysis of the organic compound used in the percentage of dry mass: $\mathrm{N}=$ $1.0 ; \mathrm{P}_{2} \mathrm{O}_{5}=1.4 ; \mathrm{K}_{2} \mathrm{O}=0.4 ; \mathrm{Ca}=6.7 ; \mathrm{Mg}=0.4 ; \mathrm{S}=$ 1.2; U-65 ${ }^{\circ} \mathrm{C}=22.0$; Total $\mathrm{MO}=20.0$; C-total $=$ 11.0 .

\section{Seedling obtainment, transplantation, plant conduction and fruit harvesting}

The cultivar Caserta was used. Sowing was performed 18 days after sowing (DAS) in 162-cell polypropylene trays containing commercial substrate Carolina Soil. The seedling transplanting took place at a spacing of $1.0 \mathrm{~m}$ between rows and $0.5 \mathrm{~m}$ between pits. The plots were constituted of fifteen plants (three rows with five plants), with only the three central plants being considered as a useful plot.

Control of spontaneous plants was done manually. Pest and disease control were not required and a sprinkler irrigation system was used, as needed by the crop.

The fruits were harvested in the mature stage, when they presented visual signs of ripeness, identified by the change in color of the stalk and cream-colored fruits. Before the seed extraction, the fruits remained at rest in laboratory environment for 15 days (CARDOSO; SOUZA NETO, 2016). Then, the fruits and seeds were washed with water and the latter were placed in clay dishes for drying for 7 to 10 days. After the extraction, the seeds were stored in a dry chamber $\left(40 \% \mathrm{RH}\right.$ and $\left.20^{\circ} \mathrm{C}\right)$, inside paper bags, until the water content stabilized at $8.0 \%$.

After this period, the seeds were subjected to cleaning to remove impurities ("rattles" and damaged ones) with the aid of the density seed separator (model "De Leo Type 1"), as described by Cardoso and Pavan (2013). Then they were used for yield and quality evaluations.

\section{Evaluated characteristics}

The number of ripe fruits per plant, seed yield per fruit, number of seeds per fruit, seed yield per plant, number of seeds per plant, mass of one thousand seeds (MTS), germination (G), first germination count test (FC), in addition to shoot length (SL) and seedling root (SR) and seedling dry matter mass were evaluated.

For $\mathrm{G}$ four replicates of 50 seeds were used, each one being placed on two sheets of paper tissue moistened with distilled water at two and a half times its dry mass, and covered with another sheet of paper tissue, then wrapped and placed in a BOD type germinator in a vertical position at $25^{\circ} \mathrm{C}$. The seeds were considered germinated when the appearance of cotyledonary leaves was observed. FC and final seedling count were performed at four and eight days after sowing (DAS), respectively, with results expressed in \%.

The evaluation of the average length of the shoot (SL) and seedling root (SR) in the FC was made with a ruler. To obtain the seedling dry mass, the total FC normal seedlings were used at eight DAS, which were placed in paper bags in an oven at $55^{\circ} \mathrm{C}$ for 48 hours. Then, the masses were measured 
on a digital scale (accuracy of $0.00001 \mathrm{~g}$ ) and the averages obtained per seedling.

The macronutrient contents were also evaluated in the diagnostic leaves, in the ripe fruits (without the seeds) and in the seeds. For the analysis of the diagnostic leaf, the fourth leaf was collected from the apical meristem of the three plants useful at $20 \mathrm{DAT}$, when the plants were beginning to flower (MALAVOLTA et al. 1997). The leaves, fruits and seeds were washed in running and deionized water and, after removal of excess moisture, were placed in a properly identified paper bag and placed for drying in a forced air circulation oven at $65{ }^{\circ} \mathrm{C}$, until they reached constant mass, according to Malavolta et al. (1997). Then, the samples were taken to the Departamento de Solos e Recursos Ambientais of FCA/UNESP, to obtain the nitrogen, phosphorus, potassium, calcium, magnesium and sulfur contents, in $\mathrm{g} \mathrm{kg}^{-1}$ of dry matter, according to methodologies presented by Malavolta et al. (1997)

\section{Statistical analysis}

Data were subjected to analysis of variance in a factorial scheme and, when significant, regression analysis was performed to verify the effect of castor bean cake doses, defining the best fit according to a combination of significance and higher coefficient of determination. To compare the splittings, the Tukey test (5\% probability) was used. The data were processed by the system Sisvar 5.3Program of Statistical Analysis and Design of Experiments of the Universidade de Lavras (FERREIRA, 2019).

\section{RESULTS AND DISCUSSION}

\section{Splittings and doses of castor bean cake: production of ripe fruits and seeds}

The interaction between the splittings and the doses of castor bean cake was not significant, and neither was the split factor for the production of ripe fruits and seeds. It seems that there is no need for several splittings during the crop cycle, facilitating the management and reducing labor.

The number of ripe fruits per plant was not influenced by the doses of castor bean cake in topdressing or by the splittings, obtaining an average of 1.7 fruits. Rech, Franke and Barros (2006), studying organic and inorganic fertilization in the production of 'Caserta' zucchini seeds, observed a significant effect on the number of fruits per plant, obtaining 1.2 fruits per plant in the control (dose 0$), 1.3$ with inorganic fertilization and 1.64 with the highest dose ( $250 \mathrm{~g}$ per pit) of poultry litter, which is lower than in the present study.

Quadratic adjustment was observed for the number of seeds per fruit, seed mass per fruit and seed mass per plant (Figure 3), obtaining maximum estimated values of 301.3 seeds, $37.5 \mathrm{~g}$ and $67 \mathrm{~g}$. at the doses of $4.0 \mathrm{t} \mathrm{ha}^{-1}, 3.6 \mathrm{t} \mathrm{ha}^{-1}$ and $4.4 \mathrm{t} \mathrm{ha}^{-1}$, respectively.

The doses of castor bean cake studied in this experiment were proportional to the amount of nitrogen recommended by Trani and Van Raij (1997). It can be noticed that there was an excess of castor bean cake and probably of nitrogen, because for most of the evaluated characteristics (except for the number of ripe fruits and the number of seeds per plant) the quadratic effect was observed. The plants reached their maximum yield with a certain dose, with a subsequent decrease. The best dose of castor bean cake, representing higher seed yield, ranged from 4.0 to $4.4 \mathrm{t} \mathrm{ha}^{-1}$. These doses correspond to 176.4 to $194 \mathrm{~kg} \mathrm{ha}^{-1}$ of $\mathrm{N}$, higher than those reported by Trani and Van Raij (1997) for zucchini. However, this recommendation is for the production of immature fruits, zucchini itself, and using inorganic fertilization. In the present research, ripe fruits were harvested with fully formed seeds, that is, there was a greater need for nutrients. In addition, organic fertilization has a slower effect than inorganic fertilizer, which justifies higher doses only if the cultivation cycle is considered. The results confirm those reported by Cardoso et al. (2011); Marcos Filho (2015) and Sá (1994) who state that plants with adequate nutrition develop better and may have higher seed production.

Satisfactory results with organic fertilization in several vegetables were also reported by other authors. Researching organic fertilization in the zucchini plantation, Rech, Franke and Barros (2006) reported increased fruit numbers and seed yield per plant as organic fertilizer doses were increased. Rocha et al. (1998), studying melon, observed higher yields using 20 and $30 \mathrm{~m}^{3} \mathrm{ha}^{-1}$ of organic compost and $50 \%$ of the recommended mineral fertilization for the crop. In broccoli, Magro et al. (2010) concluded that there was a linear increase in seed production as the doses of organic compost increased up to $120 \mathrm{t} \mathrm{ha}^{-1}$, without affecting their quality. Also, Quadros et al. (2012) observed that there was an increase in the number of lettuce seeds with organic compost fertilization with and without phosphorus addition before planting. 


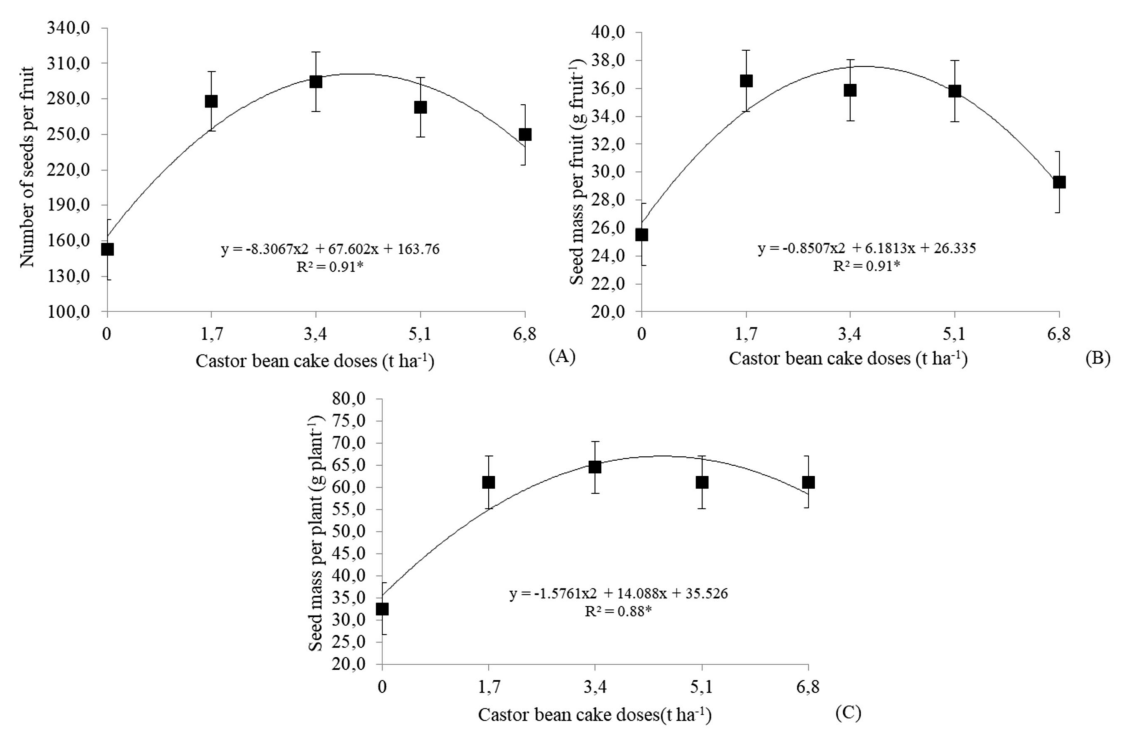

Figure 3. Number of seeds per fruit, seed mass per fruit and seed mass per plant of zucchini in relation to doses of castor bean cake in top-dressing.

FCA/UNESP, São Manuel-SP, 2015.

\section{Splittings and doses of castor bean cake: seed quality}

No significant interaction was observed between doses and splittings for mass of one thousand seeds (MTS), first germination count test (FC), germination, root length and seedling shoot mass. The doses of castor bean cake had a significant effect for most seed quality characteristics.

A quadratic effect was observed for the mass of one thousand seeds as a function of castor bean cake doses (Figure 4) with an estimated maximum value of $131.4 \mathrm{~g}$ at $4 \mathrm{tha}^{-1}$. The values obtained were slightly lower than those reported by Rech, Franke and Barros (2006), 152.5 g, when evaluating organic fertilization at planting and similar to those of Lima, Cardoso and Verdial (2003), 98 to $129 \mathrm{~g}$, when they studied pollen spacing and amount in the production of zucchini seeds, both with the same cv. Caserta. It is important to highlight that both in this research and in that of Lima, Cardoso and Verdial (2003) seeds were evaluated after beneficiation and with similar water content, $8 \%$, while in Rech, Franke and Barros (2006) this information is not reported.

For germination (Figure 4), the data fit the quadratic model, with an estimated maximum value of $95.7 \%$ for the $4.9 \mathrm{t} \mathrm{ha}^{-1}$ dose. Rech, Franke and Barros (2006) found minimum and maximum values of 85 and $92 \%$, which are similar to those found in the present study. It can be seen that all values are above the minimum accepted for marketing by MAPA (75\%), and the lowest estimated value was $90 \%$ at $0.0 \mathrm{t} \mathrm{ha}^{-1}$. However, according to Cardoso,
Peñalosa and Nascimento (2014), considering the competitiveness among companies in this market, these official standards are out of line with market practice, making it difficult to sell seeds with less than 85 to $90 \%$ germination in cucurbits. However, even by this standard, all treatments would result in seeds with greater competitive advantage. For FC (Figure 4) a quadratic effect was also observed, with maximum vigor estimated at $95 \%$ at $4.4 \mathrm{t} \mathrm{ha}^{-1}$.

The values for seedling root length (Figure 4) were adjusted to the linear equation, and for each $1 \mathrm{t} \mathrm{ha}^{-1}$ of castor bean cake in top-dressing, an increase of $0.08 \mathrm{~cm}$ of seedling root was increased. Sá (1994) reports that the nutritional aspect of plants affects seed size, mass and vigor, and in many cases these effects are linked to the permeability and integrity of tissue membranes, where nutrients act as enzyme activators, or constitute these membranes. Normally, more nourished seeds with larger mass may present greater physiological potential, that is, better germination and vigor. The mass of a thousand seeds, germination and FC presented their data adjusted to the model maximum values with doses ranging from 4.0 to $4.9 \mathrm{t} \mathrm{ha}^{-1}$ of castor bean cake top-dressing. In addition, these doses also resulted in higher seed production (Figure 3 ).

Taking into consideration that castor bean cake is high in nitrogen, translocated in considerable quantities during seed formation, in which the nutritional requirement becomes more intense, the fertilization with the castor bean cake can be a practice that contributes to quality and also seed production. 

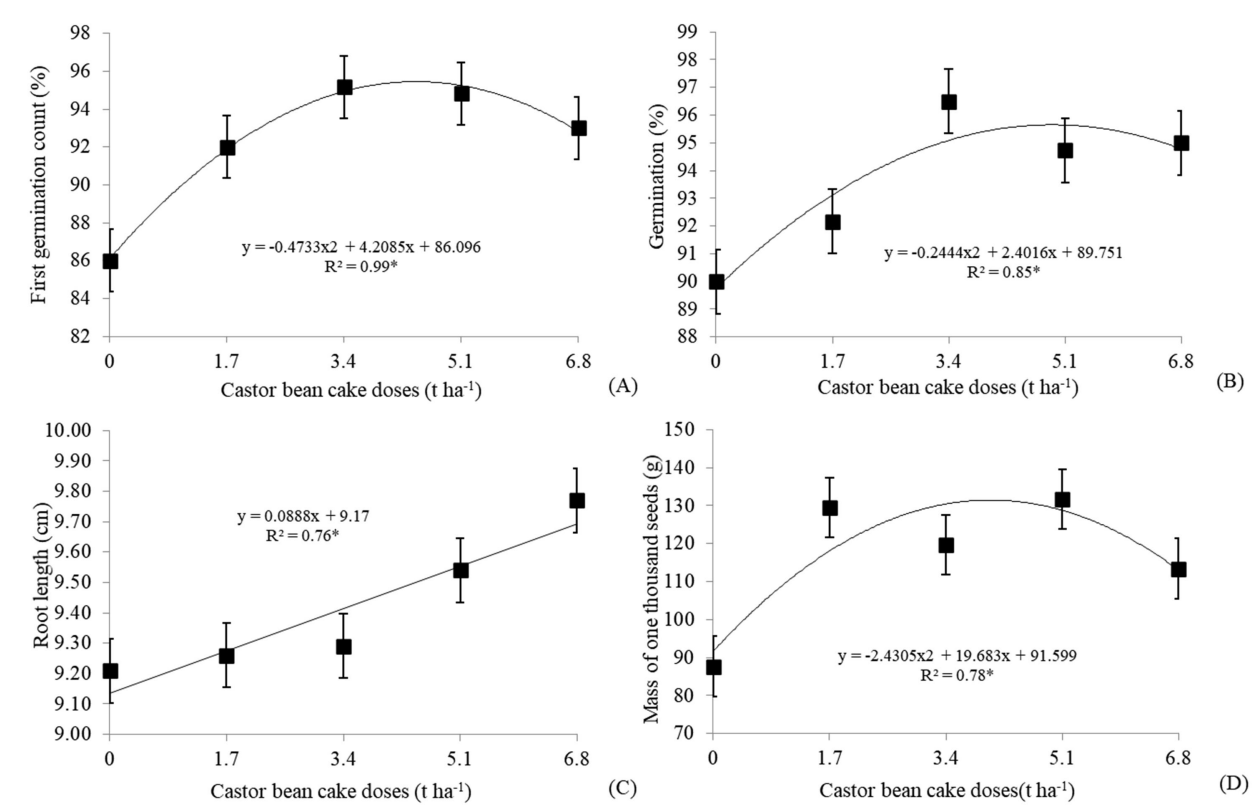

Figure 4. First germination count, total germination, root length and mass of one thousand seeds of zucchini in relation to doses of castor bean cake in top-dressing. FCA/UNESP, São Manuel-SP, 2015.

Splittings and doses of castor bean cake: macronutrient contents of the diagnostic leaf

The splitting factor was significant for the $\mathrm{N}$ and $\mathrm{S}$ contents, while the dose factor was significant for the levels of all macronutrients. For P, K, Ca and $\mathrm{Mg}$ there was no difference between the splittings, with mean averages of $5.5,53.3$ and $3.6 \mathrm{~g} \mathrm{~kg}^{-1}$ of $\mathrm{DM}$, respectively. Lower levels of $\mathrm{N}$ and $\mathrm{S}$ were observed in the diagnostic leaf for the split 33.3$33.3-33.3 \%$ (Table 1). This was the splitting application where the lowest proportion of castor bean cake was placed at the beginning of the cycle. Perhaps, that is why the contents of these nutrients were lower at this stage of the cycle where not all the fertilizer had been used, that is, it was the treatment which, for each dose, always received the lowest amount of fertilizer (only 33\%) compared to the other two splitting applications that received $50 \%$ of the dose at this stage of the cycle.

Table 1. Mean content of nitrogen, phosphorus, potassium, calcium, magnesium and sulfur in the diagnostic leaf for each splitting.

\begin{tabular}{llccccc}
\hline Splitting & Nitrogen & Phosphorus & Potassium & Calcium & Magnesium & Sulfur \\
\hline & \multicolumn{7}{c}{$\mathrm{g} \mathrm{kg}^{-1}$ dry matter } \\
$33.3-33.3-33.3$ & $40.0 \mathrm{~b}$ & $5.5 \mathrm{a}$ & $53.3 \mathrm{a}$ & $12.9 \mathrm{a}$ & $3.7 \mathrm{a}$ & $1.1 \mathrm{~b}$ \\
$50-50$ & $43.0 \mathrm{ab}$ & $5.5 \mathrm{a}$ & $54.3 \mathrm{a}$ & $11.8 \mathrm{a}$ & $3.5 \mathrm{a}$ & $1.2 \mathrm{a}$ \\
$50-33-17$ & $43.5 \mathrm{a}$ & $5.5 \mathrm{a}$ & $52.5 \mathrm{a}$ & $11.9 \mathrm{a}$ & $3.6 \mathrm{a}$ & $1.2 \mathrm{a}$ \\
\hline
\end{tabular}

FCA/UNESP, São Manuel-SP, 2015.

Means followed by same letter do not differ according to Tukey test (5\% probability).

For nitrogen, phosphorus and potassium, there was an increasing linear effect. For calcium and magnesium there was a decreasing linear effect, and for sulfur a quadratic effect (Figure 5). For each $1 \mathrm{t} \mathrm{ha}^{-1}$ of castor bean cake top-dressing, the $\mathrm{N}, \mathrm{P}$ and $\mathrm{K}$ content was increased by $2.6 \mathrm{~g} \mathrm{~kg}^{-1} ; 0.3 \mathrm{~g} \mathrm{~kg}^{-1}$ and $0.8 \mathrm{~g} \mathrm{~kg}^{-1}$, respectively, and the $\mathrm{Ca}$ and $\mathrm{Mg}$ content was reduced by $1.105 \mathrm{~g} \mathrm{~kg}^{-1}$ and $0.08 \mathrm{~g} \mathrm{~kg}^{-1}$ respectively. The increase in $\mathrm{N}$ content is due to the high content of this nutrient in castor bean cake $(5.7 \% \mathrm{~N})$, while $\mathrm{K}$, despite its relatively small content $(0.9 \% \mathrm{~K})$, is more easily mineralized from organic and highly mobile fertilizers on plants (MAGRO et al. 2015; MALAVOLTA, 2006). On the other hand, the increase of $\mathrm{K}$ may impair the absorption of other cations: $\mathrm{Ca}++$ and $\mathrm{Mg}++$ (MALAVOLTA, 2006), therefore, probably reducing the content of these nutrients in the diagnostic leaf. The same was observed in squash (ARAÚJO et al. 2012) and in zucchini (ARAÚJO et al. 2015), where the increase of potassium doses applied in the top-dressing caused a reduction in $\mathrm{Ca}$ content in leaves. 
As for $\mathrm{S}$ the effect was quadratic (Figure 5). However, although significant, the differences were small, ranging from $1.0322 \mathrm{~g} \mathrm{~kg}^{-1}$ at dose $0 \mathrm{t} \mathrm{ha}^{-1}$ to the maximum content estimated at $1.2 \mathrm{~g} \mathrm{~kg}^{-1}$ for the dose $4.6 \mathrm{tha}^{-1}$.
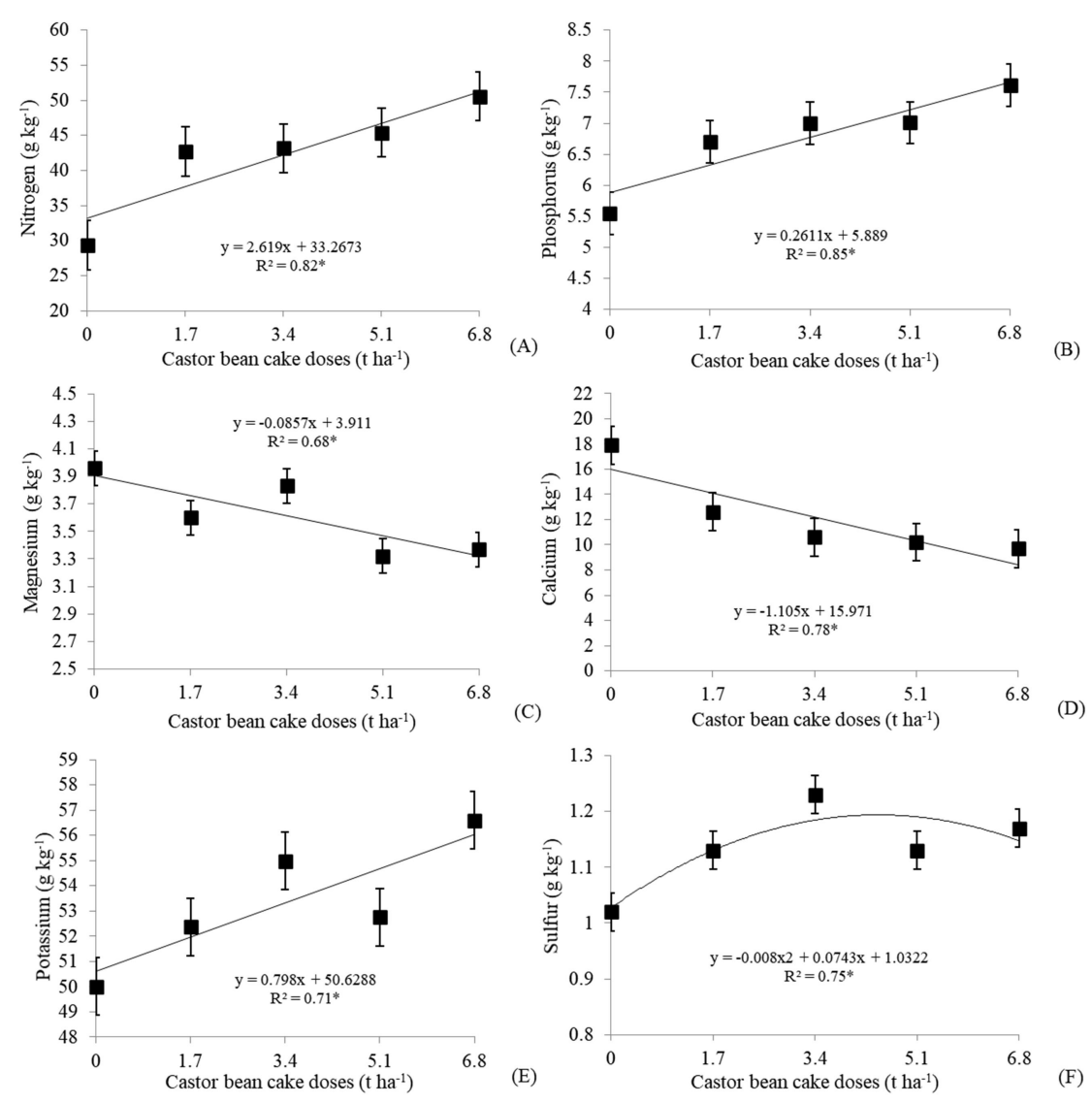

Figure 5. Nitrogen, phosphorus, potassium, calcium, magnesium and sulfur content in zucchini diagnostic leaf in relation to doses of castor bean cake in top-dressing.

FCA/UNESP, São Manuel-SP, 2015.

\section{Doses and splittings of castor bean cake: macronutrient contents in ripe fruits without seeds}

Significant effects of castor bean cake doses were observed for the content of most macronutrients in mature fruits without seeds, except for magnesium, for which an average of 13.9 $\mathrm{g} \mathrm{kg}^{-1}$ of dry matter (DM) was obtained (Figure 6). No significant effects were observed for the splittings factor, while the dose-splitting interaction was significant only for nitrogen (Figure 7).

A linear effect was observed for the castor bean cake in the three splittings for nitrogen content, with an increase of $1.9 ; 0.9$ and $1.5 \mathrm{~g} \mathrm{~kg}^{-1}$ MS in the splittings 33.3-33.3-33.3\%, 50-50\% and 50-33-17\%, respectively (Figure 7).

For phosphorus, potassium and sulfur a quadratic effect was observed, with maximum levels estimated at 10.3; 99.4 and $1.4 \mathrm{~g} \mathrm{~kg}^{-1} \mathrm{DM}$ at doses of 3.8; 3.9 and $4.7 \mathrm{t} \mathrm{ha}^{-1}$, respectively. (Figure 6). For these three macronutrients, after reaching their maximum value, their levels were practically stabilized up to the highest dose $\left(6.8 \mathrm{t} \mathrm{ha}^{-1}\right)$, with small reductions in values.

Calcium was the only macronutrient that showed a decreasing linear effect. For each $1 \mathrm{t} \mathrm{ha}^{-1}$ the content of this macronutrient decreased by $0.2 \mathrm{~g}$ $\mathrm{kg}^{-1}$ DM. The increase in potassium content may have favored competition for the cationic absorption site, and thus resulted in a reduction in calcium content. This same trend was observed by Büll et al. (2001) and by Araújo et al. (2015) regarding the cultivation of noble garlic and zucchini, respectively. Another explanation is that this nutrient is poorly mobile in the plant (MALAVOLTA, 2006), being more accumulated in the leaves, which have a large surface of perspiration, whereas the fruits have a small surface. 
Additionally, with the increase in fruit size in the highest doses of castor bean cake, the "dilution effect" of this nutrient probably occurred.

The decreasing order of macronutrient content in fruits was as follows: $\mathrm{K}>\mathrm{N}>\mathrm{P}>\mathrm{Ca}>$ $\mathrm{Mg}>\mathrm{S}$. Araújo et al. (2015) found a similar order to the present research, but in immature zucchini fruits.
LANNA, N. B. L. et al.

Potassium stood out as the nutrient with the highest content, which was also reported in fruits of other cucurbits: Vidigal, Pacheco and Facion (2007) with pumpkin 'Tetsukabuto', Araújo et al. (2012) with pumpkin 'Miriam', Grangeiro and Cecílio Filho (2004) in watermelon and (SILVA et al., 2006) in melon.
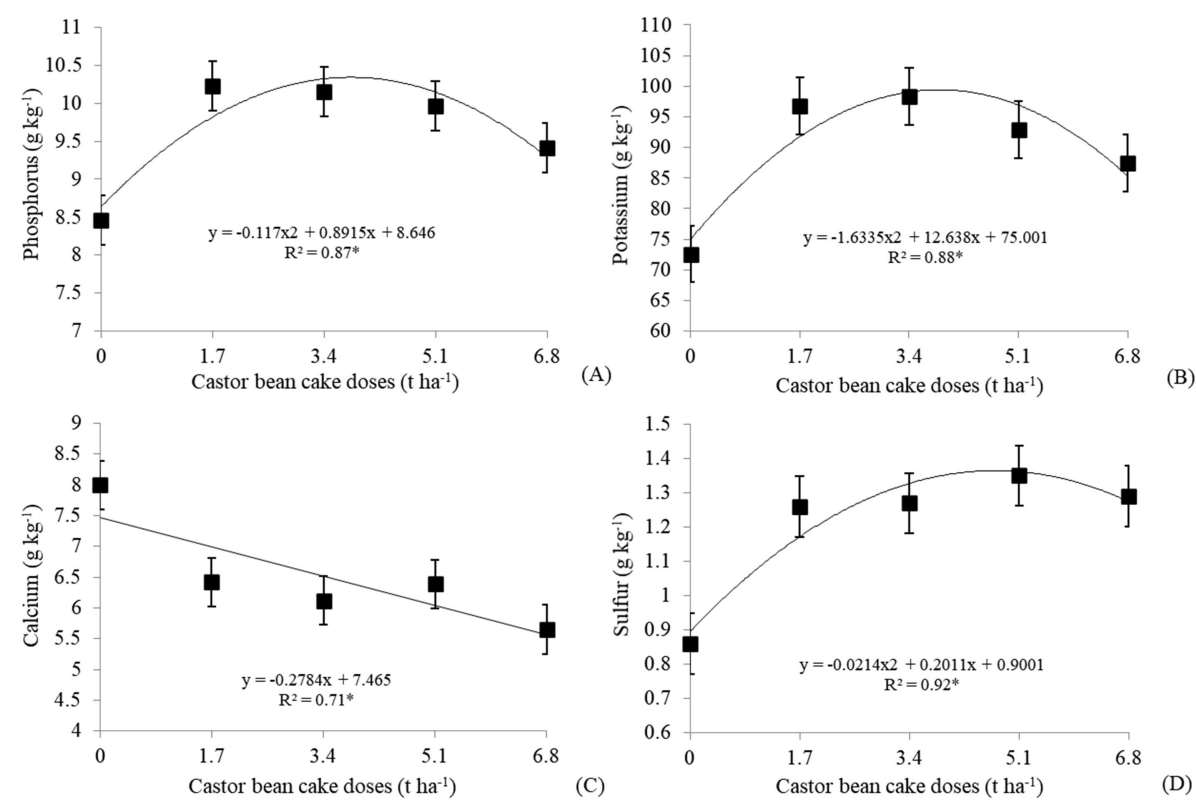

Figure 6. Phosphorus, potassium, calcium and sulfur content in mature fruits (without the seeds) of zucchini in relation to doses of castor bean cake in top-dressing. FCA/UNESP, São Manuel-SP, 2015.

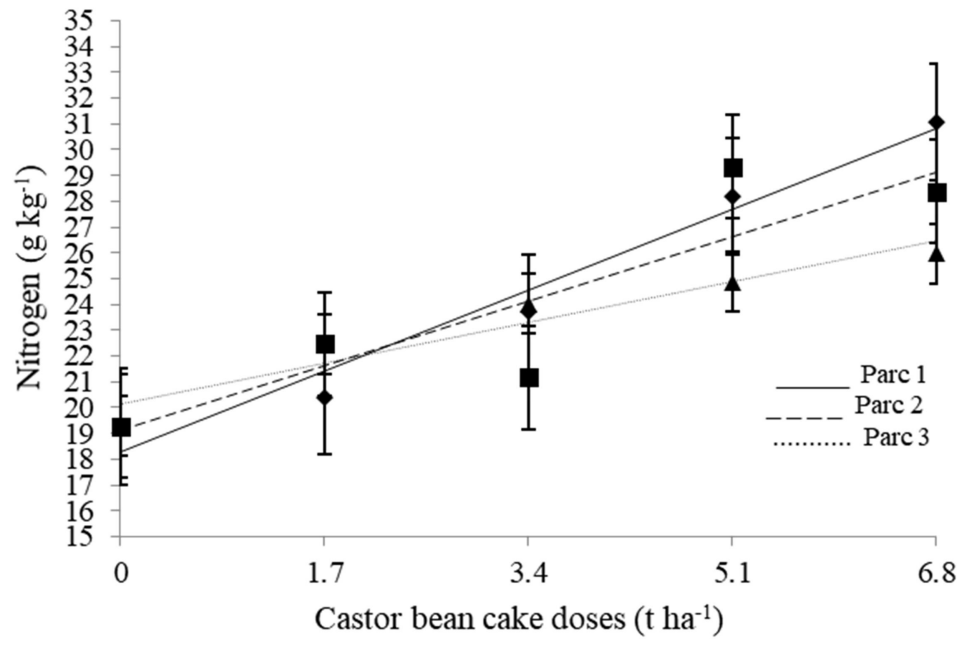

$$
\begin{array}{ccc}
\mathrm{yp}^{1}=1.845 \mathrm{x}+18.257 & \mathrm{yp}^{2}=0.9319 \mathrm{x}+20.15 & \mathrm{yp}^{3}=1.4741 \mathrm{x}+19.108 \\
\mathrm{R}^{2}=0.97^{*} & \mathrm{R}^{2}=0.92^{*} & \mathrm{R}^{2}=0.78^{*}
\end{array}
$$

Figure 7. Nitrogen content in mature fruits (without the seeds) of zucchini in relation to doses of castor bean cake in top-dressing at the splittings.

FCA/UNESP, São Manuel-SP, 2015 
An interaction of the splittings factor in relation to the doses of castor bean cake was only observed for nitrogen (Table 2). Only at the highest doses (5.1 and $6.8 \mathrm{t} \mathrm{ha}^{-1}$ ) was a difference observed for the splittings, and the splitting 50-50\% presented the lowest values. Considering that this was the treatment with the highest proportion of $\mathrm{CBC}$ at the end of the cycle and that this fertilizer presents slower nutrient release, this may imply a lower $\mathrm{N}$ content when there is greater availability of this nutrient in the soil with the highest doses.
In addition, the nitrogen split reduces leaching, especially in sandy soils (which is the case of this research), which, due to low organic matter and clay and lower water storage capacity, increases the percolation of particles of soil and nutrients. So, in the $50-50 \%$ splitting this element may have leached since it was applied with a greater concentration, with only two splittings.

Table 2. Mean content of nitrogen of mature fruits, without seeds for each splitting for each of the castor bean cake doses.

\begin{tabular}{lcllll}
\hline & Doses $\left(\mathrm{t} \mathrm{ha}^{-1}\right)$ & & & & \\
Splitting & 0 & 1.7 & 3.4 & 5.1 & 6.8 \\
\hline $33.3-33.3-33.3$ & $19.3 \mathrm{a}$ & $20.4 \mathrm{a}$ & $23.7 \mathrm{a}$ & $28.2 \mathrm{ab}$ & $31.0 \mathrm{a}$ \\
$50-50$ & $19.3 \mathrm{a}$ & $22.4 \mathrm{a}$ & $24.0 \mathrm{a}$ & $24.8 \mathrm{~b}$ & $25.9 \mathrm{~b}$ \\
$50-33-17$ & $19.3 \mathrm{a}$ & $22.5 \mathrm{a}$ & $21.2 \mathrm{a}$ & $29.3 \mathrm{a}$ & $28.4 \mathrm{ab}$ \\
\hline
\end{tabular}

FCA/UNESP, São Manuel-SP, 2015

Means followed by same letter do not differ according to Tukey test ( $5 \%$ probability).

\section{Doses and splittings of castor bean cake: macronutrient contents in seeds}

There was no interaction between castor bean cake rates and split rates for the levels of all macronutrients in the seeds, nor was there any difference between splittings for all macronutrients. On the other hand, for the castor bean cake doses, a statistical difference was observed for the contents of all of them (Figure 8).

Only for potassium was a linear effect observed, and for the other nutrients a quadratic effect (Figure 8). For each $1 \mathrm{t} \mathrm{ha}^{-1}$ of castor bean cake top-dressing, the potassium content of the seeds was increased by $0.19 \mathrm{~g} \mathrm{~kg}^{-1} \mathrm{DM}$. In addition to potassium being a highly mobile element in the plant, generally all $\mathrm{K}$ in organic fertilizers is already mineralized and, therefore, has a similar availability to the $\mathrm{K}$ from mineral fertilizers (ERNANI; BAYER; ALMEIDA, 2007).

The average maximum levels of nitrogen, phosphorus, calcium, magnesium and sulfur were estimated at 54.1; 11.4; 1.4; 5.6 and $1.1 \mathrm{~g} \mathrm{~kg}^{-1} \mathrm{DM}$, respectively, at doses ranging from 4.1 to $4.8 \mathrm{t} \mathrm{ha}^{-1}$ (Figure 7). For nitrogen, phosphorus and magnesium, after reaching the maximum value, the seed contents practically stabilized up to the highest dose $\left(6.8 \mathrm{t} \mathrm{ha}^{-1}\right)$, while for calcium and sulfur the reductions in the contents were more pronounced.

The decreasing order of macronutrient contents in the seeds was: $\mathrm{N}>\mathrm{P}>\mathrm{K}>\mathrm{Mg}>\mathrm{Ca}>\mathrm{S} . \mathrm{N}$ was the nutrient with the highest content in seeds. Similar results were obtained with lettuce (KANO et al. 2011) and broccoli seeds (MAGRO et al. 2010). Cardoso (2011), in a review including several vegetables, reported that the accumulation of $\mathrm{N}$ in the seeds was always greater than that of the other nutrients. This demonstrates the importance of this element $(\mathrm{N})$ in the seed composition, usually rich in proteins, besides being a nutrient that is easily redistributed in the plant to the reproductive parts (MALAVOLTA, 2006).

$\mathrm{P}$ was the second macronutrient with the highest content in seeds. As reported by Carvalho and Nakagawa (2012), phosphorus compounds are of great importance in the various reactions that occur in seeds. Thus, phosphorus is a constituent of the nucleic acid molecule, which in turn is related to protein synthesis. It also includes phospholipids, phosphorus sugars, nucleotides and phytin, which is a calcium and magnesium salt. These nutrients $(\mathrm{N}$ and $\mathrm{P}$ ) are the most important in seed formation of the vast majority of species, as reported by several authors (CARDOSO, 2011). Whereas Mg, Ca and S were the macronutrients with the lowest contents in seeds, similar to that reported by Kano et al. (2011) on lettuce. Despite the importance of calcium, it is a poorly accumulated nutrient in seeds, a fact probably related to its low mobility in the plant by phloem (MALAVOLTA, 2006). 

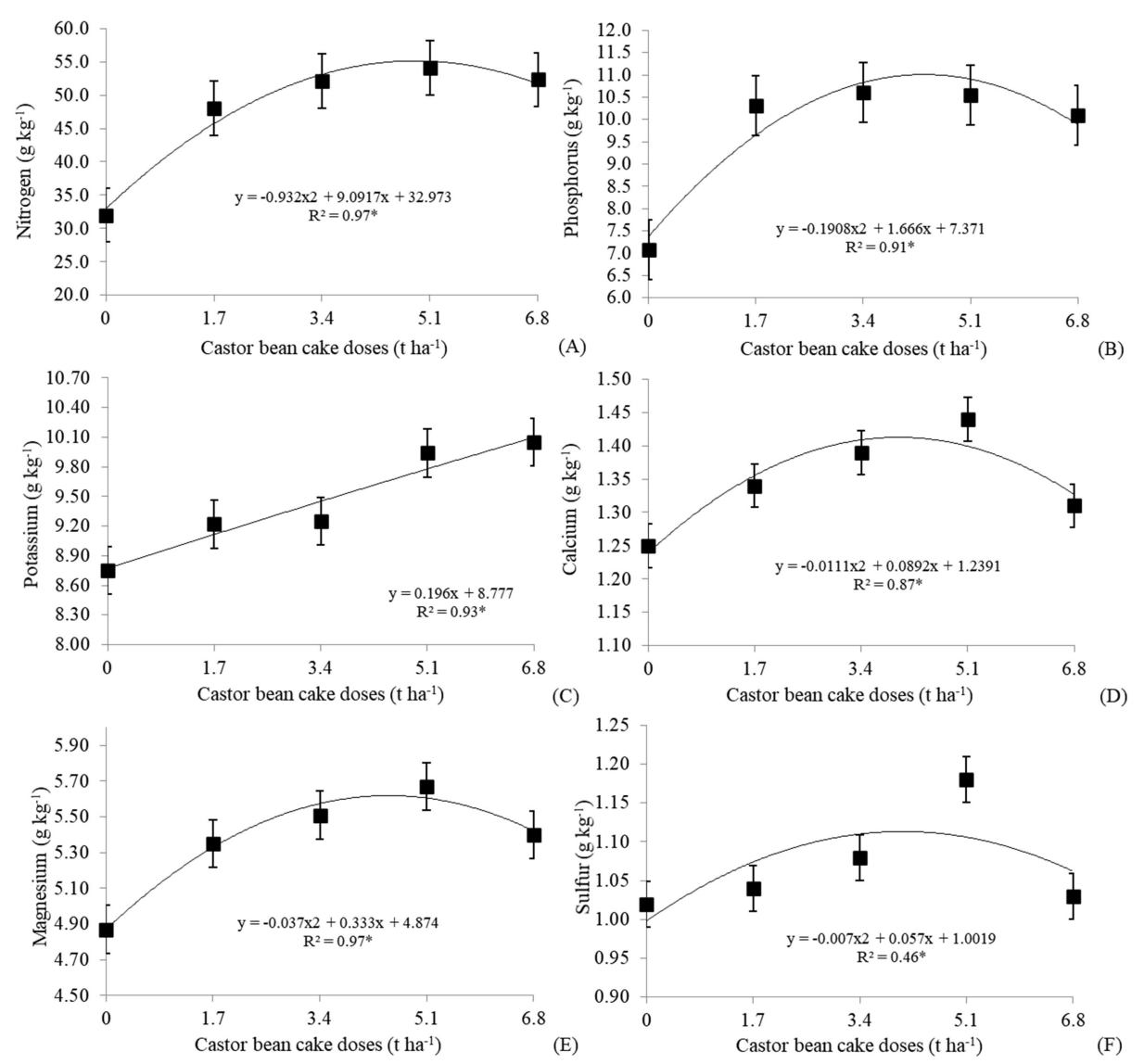

Figure 8. Nitrogen, phosphorus, potassium, calcium, magnesium and sulfur content in zucchini seeds in relation to doses of castor bean cake in top-dressing.

FCA/UNESP, São Manuel-SP, 2015.

\section{CONCLUSIONS}

Doses of castor bean cake increased the number of seeds per fruit, mass of seeds per fruit and seed mass per plant up to $4.5 \mathrm{tha}^{-1}$.

The doses of castor cake and the splittings did not influence the quality of the seeds.

It was observed that there is no need for multiple splittings of castor bean cake during the crop cycle, which facilitates management and reduces labor.
The decreasing order of macronutrient contents in the seeds was: $\mathrm{N}>\mathrm{P}>\mathrm{K}>\mathrm{Mg}>\mathrm{Ca}>\mathrm{S}$; in the diagnostic leaf it was $\mathrm{K}>\mathrm{N}>\mathrm{Ca}>\mathrm{P}>\mathrm{Mg}>\mathrm{S}$; and in the ripe fruits it was $\mathrm{K}>\mathrm{N}>\mathrm{P}>\mathrm{Ca}>\mathrm{Mg}>\mathrm{S}$.

\section{ACKNOWLEDGMENTS}

This study was financed in part by the Coordenação de Aperfeiçoamento de Pessoal de Nível Superior - Brasil (CAPES) - Finance Code 001 .

RESUMO: Trabalhos em horticultura já realizados mostram que a adubação influencia positivamente na produção de sementes, porém, ao se analisar a qualidade das sementes, os resultados na maioria das vezes não são concordantes. O objetivo do trabalho foi de estudar o efeito de parcelamentos e doses de torta de mamona (TM) em cobertura na produção e qualidade de sementes orgânicas de abobrinha-de-moita, assim como nos teores de macronutrientes nos frutos e sementes. Foi utilizado o delineamento experimental em blocos ao acaso, e quatro repetições. Totalizaram 13 tratamentos, sendo quatro doses de TM em cobertura $(1,7$; 3,$4 ; 5,1$ e $\left.6,8 \mathrm{t} \mathrm{ha}^{-1}\right) \times$ três parcelamentos das aplicações $(33,3-33,3-33,3 \% ; 50-50 \%$ e $33-50-17 \%)$ e o controle sem nenhum tipo de adubação em cobertura. Foram avaliados o número de frutos maduros por planta, produção (número e massa) de sementes por fruto e por planta, massa de mil sementes, germinação, primeira contagem de germinação e teores de macronutrientes na folha diagnose, nos frutos maduros (sem as sementes) e nas sementes. O número de frutos maduros por planta não foi influenciado pelas doses de TM em cobertura nem 
pelos parcelamentos. Observou-se ajuste quadrático para o número de sementes por fruto, massa de sementes por fruto e massa de sementes por planta. Para a qualidade das sementes as doses de 1,$7 ; 3,4 ;$ e $5,1 \mathrm{t} \mathrm{ha}^{-1}$ foram superiores às demais doses. Pode-se concluir que as doses de TM aumentaram o número de sementes por fruto, massa de sementes por fruto e massa de sementes por planta até a dose $4,5 \mathrm{t} \mathrm{ha}^{-1}$, aproximadamente.

Vigor.

PALAVRAS-CHAVE: Adubação nitrogenada. Adubação orgânica. Cucurbita pepo. Germinação.

\section{REFERENCES}

ARAÚJO, H. S.; QUADROS, B. R.; CARDOSO, A. A. I.; CORRÊA, C. V. Topdressing potassium doses on squash crop. Pesquisa Agropecuária Tropical, Goiânia, v. 42, n. 4, p. 469-475, 2012.

https://doi.org/10.1590/S1983-40632012000400004

ARAÚJO, H. S.; CARDOSO, A. A. I.; OLIVEIRA JÚNIOR, M. X.; MAGRO, F. O. Macronutrients content and extraction in zucchini plants in function of potassium top dressing levels. Agrária, Recife, v. 10, n. 3, p. 389-395, 2015. https://doi.org/10.5039/agraria.v10i3a4937

BÜLL, L. T.; VILLAS BOAS, R. L.; FERNANDES, D. M.; BERTANI, R. M. A. Fertilização potássica na cultura do alho vernalizado. Scientia Agrícola, Piracicaba, v. 58, n. 1, p. 157-163, 2001.

https://doi.org/10.1590/S0103-90162001000100024

CARDOSO, A. I. I. Nutrição e adubação em campos de produção de sementes de hortaliças. In:

NASCIMENTO, W. M. (Ed.). Hortaliças: tecnologia de produção de sementes. Brasília: Embrapa

Hortaliças, 2011. p.109-134.

CARDOSO, A. I. I.; FERREIRA, K.; VIEIRA JÚNIOR, R. M.; ALCARDE, C. Alterações em propriedades do solo adubado com composto orgânico e efeito na qualidade das sementes de alface. Horticultura Brasileira, Brasília, v. 29, n. 4, p. 594-599, 2011. https://doi.org/10.1590/S0102-05362011000400025

CARDOSO, A. I. I.; PAVAN, M. A. Premunização de plantas afetando a produção de frutos e sementes de abobrinha-de-moita. Horticultura Brasileira, Vitória da Conquista, v. 31, n. 1, p. 45-49, 2013.

https://doi.org/10.1590/S0102-05362013000100007

CARDOSO, A. I. I.; PEÑAlOSA, P.; NASCIMENTO, W. M. Produção de sementes de pepino. In: NASCIMENTO, W. M. (Ed.). Hortaliças: tecnologia de produção de sementes. Brasília: Embrapa Hortaliças, 2014. p.139-165.

CARDOSO, A. I.I.; SOUZA NETO, I. L. Melhoramento de abóbora, abobrinha e moranga. In: NICK, C. \& BORÉM, A. (Ed). Melhoramento de Hortaliças. Viçosa: Editora UFV, 2016. p. 61-94.

CARVALHO, N.M. e NAKAGAWA, J. Sementes: ciência, tecnologia e produção. $4^{\mathrm{a}}$ ed. Jaboticabal: Funep, 2012. ISBN 85-87632-01-9 1.

CUNHA, A. R.; MARTINS, D. Climatic classification for the districts of Botucatu and São Manuel, sp. Irriga, Botucatu, v. 14, n. 1, p. 1-11, 2009. https://doi.org/10.15809/irriga.2009v14n1p1-11

ERNANI, P. R.; BAYER, C.; ALMEIDA, J. A. Vertical mobility of cations as influenced by the method of potassium chloride application to variable charge soils. Revista Brasileira de Ciência do Solo, Viçosa, v. 31, n. 2, p. 393-402, 2007. https://doi.org/10.1590/S0100-06832007000200022

FERREIRA, D. F. Sisvar: a computer statistical analysis system to fixed effects split plot type designs. Revista Brasileira de Biometria, Lavras, v. 37, n. 4, p. 529-535, 2019. https://doi.org/10.28951/rbb.v37i4.450 
GRANGEIRO, L. C.; CECÍLIO FILHO, A. B. Acúmulo e exportação de macronutrientes pelo híbrido de melancia Tide. Horticultura Brasileira, Brasília, v. 22, n. 1, p. 93-97, 2004. https://doi.org/10.1590/S0102$\underline{05362004000100019}$

KANO, C.; CARDOSO, A. A. I.; VILLAS BÔAS, R. L.; HIGUTI, A. R. O. Germinação de sementes de alface obtidas de plantas cultivadas com diferentes doses de fósforo. Semina. Ciências Agrárias, Londrina, v.32 n. 2 , p.591-598, 2011. https://doi.org/10.5433/1679-0359.2011v32n2p591

LIMA, M. S; CARDOSO, A. I. I.; VERDIAL, M. F. Plant spacing pollen quantity on yield and quality of squash seed. Horticultura Brasileira, Brasília, v. 21, n. 3, p. 443-447, 2003. https://doi.org/10.1590/S0102$\underline{05362003000300005}$

MAGRO, F. O.; ARRUDA, N.; CASA, J.; SALATA, A. C.; CARDOSO, A. A. I.; FERNANDES, D. M. Composto orgânico na produção e qualidade de sementes de brócolis. Ciência e Agrotecnologia, Lavras, v. 34, n. 3, p. 596-602, 2010. https://doi.org/10.1590/S1413-70542010000300010

MAGRO, F. O.; CARDOSO, A. I. I.; FERNANDES, D. M. Composto orgânico no potencial fisiológico de sementes de brócolis após o armazenamento. Semina ,Londrina, v. 33, n. 3, p. 1033-1040, 2012.

https://doi.org/10.5433/1679-0359.2012v33n3p1033

MAGRO, F. O.; SILVA, E. G.; TAKATA, W. H. S.; CARDOSO, A. A. I.; FERNANDES, D. M.;

EVANGELISTA, R. M. Organic compost and potassium top dressing fertilization on production and quality of beetroot. Australian Journal and Crop Science, Austrália, v. 9, n. 10, p. 962-967, 2015.

MALAVOLTA, E. Manual de nutrição mineral de plantas. São Paulo: Agronômica Ceres, 2006. ISBN 85318-0047-1.

MALAVOLTA, E.; VITTI, G. C.; OLIVEIRA, S. A. Avaliação do estado nutricional das plantas, princípios e aplicações. $2^{a}$ ed. Piracicaba: Potafós, 1997. 319 p.

MARCOS FILHO, J. Fisiologia de sementes de plantas cultivadas. $3^{\text {a }}$ ed. Londrina: ABRATES, 2015. ISBN 978-85-64895-03-4.

QUADROS, B. R.; CORRÊA, C. V.; MAGRO, F. O.; CARDOSO, A. A. I. Influência de composto orgânico e fósforo sobre sementes de alface. Semina. Ciências Agrárias. Londrina, v. 33, n. 1, p. 2511-2518, 2012. https://doi.org/10.5433/1679-0359.2012v33Sup11p2511

RECH, E. G.; FRANKE, L. B.; BARROS, I. B. I. Adubação orgânica e mineral na produção de sementes de abobrinha. Revista Brasileira de Sementes, Pelotas, v. 18, n. 2, p. 110- 116, 2006.

https://doi.org/10.1590/S0101-31222006000200014

ROCHA, R. C.; FARIA, C. M. B.; COSTA, N. D.; CAMPOS, C. O. Influência da adubação organo-mineral na qualidade e produtividade de frutos de melão. Horticultura Brasileira, Brasília, v. 167, n. 291, p. 135-140, 1998.

SÁ, M. E. Importância da adubação na qualidade de semente. In: SÁ, M. E. \& BUZZETI, S.

(Ed.). Importância da adubação na qualidade dos produtos agrícolas. São Paulo: Ícone, 1994. p.65-98.

SILVA, M. J.; MEDEIROS, J. F.; OLIVEIRA, F. H. T.; DUTRA, I. Dry matter accumulation and nutrient uptake by "pele-de-sapo" melon plants. Revista Brasileira de Engenharia Agrícola e Ambiental, Campina Grande, v. 10, n. 2, p. 364-368, 2006. https://doi.org/10.1590/S1415-43662006000200017

SILVA, P. N. L.; LANNA, N. B. L.; CARDOSO, A. A. I. Beet production depending on rates of castor bean cake as topdressing. Horticultura Brasileira, Brasília, v. 34, n. 3, p. 416-421, 2016.

https://doi.org/10.1590/S0102-05362016003018 
TRANI, P. E.; VAN. RAIJ, B. Hortaliças. In: Raij B. Van (Ed.). Recomendações de adubação e calagem para o Estado de São Paulo. Campinas: Instituto Agronômico \& Fundação IAC, 1997. p. 87-90.

VIDIGAL, S. M.; PACHECO, D. D.; FACION, C. E. Growth and accumulation of nutrients in hybrid squash Tetsukabuto. Horticultura Brasileira, Brasília, v. 25, n. 3, p. 375- 380, 2007. https://doi.org/10.1590/S0102$\underline{05362007000300011}$ 